\title{
Isolation of Pantoea ananatis from sugarcane and characterization of its potential for plant growth promotion
}

\author{
J.F. da Silva ${ }^{1}$, R.R. Barbosa ${ }^{1}$, A.N. de Souza', O.V. da Motta ${ }^{2}$, G.N. Teixeira ${ }^{2}$, \\ V.S. Carvalho ${ }^{3}$, A.L.S.R de Souza ${ }^{1}$ and G.A. de Souza Filho ${ }^{1}$ \\ 'Laboratório de Biotecnologia, Centro de Biociências e Biotecnologia, \\ Universidade Estadual do Norte Fluminense Darcy Ribeiro, Campos dos Goytacazes, \\ RJ, Brasil \\ 'Laboratório de Sanidade Animal, Centro de Ciências e Tecnologias Agropecuárias, \\ Universidade Estadual do Norte Fluminense Darcy Ribeiro, Campos dos Goytacazes, \\ RJ, Brasil \\ ${ }^{3}$ Laboratório de Fitotecnia, Centro de Ciências e Tecnologia Agropecuária, \\ Universidade Estadual do Norte Fluminense Darcy Ribeiro, Campos dos Goytacazes, \\ RJ, Brasil
}

Corresponding author: G.A. de Souza Filho

E-mail: goncalos@uenf.br

Genet. Mol. Res. 14 (4): 15301-15311 (2015)

Received May 14, 2015

Accepted August 13, 2015

Published November 30, 2015

DOI http://dx.doi.org/10.4238/2015.November.30.6

\begin{abstract}
Each year, approximately 170 million metric tons of chemical fertilizer are consumed by global agriculture. Furthermore, some chemical fertilizers contain toxic by-products and their long-term use may contaminate groundwater, lakes, and rivers. The use of plant growthpromoting bacteria may be a cost-effective strategy for partially replacing conventional chemical fertilizers, and may become an integrated plant nutrient solution for sustainable crop production. The main direct bacteriaactivated mechanisms of plant growth promotion are based on improvement of nutrient acquisition, siderophore biosynthesis, nitrogen fixation, and hormonal stimulation. The aim of this study was to isolate and identify
\end{abstract}


bacteria with growth-promoting activities from sugarcane. We extracted the bacterial isolate SCB4789F-1 from sugarcane leaves and characterized it with regard to its profile of growth-promoting activities, including its ability to colonize Arabidopsis thaliana. Based on its biochemical characteristics and $16 \mathrm{~S}$ rDNA sequence analysis, this isolate was identified as Pantoea ananatis. The bacteria were efficient at phosphate and zinc solubilization, and production of siderophores and indole-3-acetic acid in vitro. The isolate was characterized by Gram staining, resistance to antibiotics, and use of carbon sources. This is the first report on zinc solubilization in vitro by this bacterium, and on plant growth promotion following its inoculation into $A$. thaliana. The beneficial effects to plants of this bacterium justify future analysis of inoculation of economically relevant crops.

Key words: Pantoea ananatis; Phosphorus solubilization; Zinc solubilization; Phytohormone production; Plant growth promotion; Arabidopsis thaliana

\section{INTRODUCTION}

Each year, approximately 170 million metric tons of chemical fertilizer are consumed by global agriculture (IFA, 2014). Furthermore, some chemical fertilizers are toxic when used in high concentration and their long-term use may damage soil and groundwater environments (Berg, 2009) with consequences for human and animal health. The use of plant growth-promoting bacteria (PGPB) may be a cost-effective strategy for partially or completely replacing conventional chemical fertilizers, and may become an integrated plant nutrient solution for sustainable crop production (Dion et al., 2010; Babar et al., 2011).

The mechanisms by which PGPB promote plant growth include phosphate and zinc solubilization activity (Verma et al., 2001; Intorne et al., 2009), production of phytohormones (Lee et al., 2004), nitrogen fixation (Compant et al., 2005), siderophore biosynthesis (Lodewyckx et al., 2002), and assisting the host plant in overcoming environmental stresses (Ryan et al., 2008).

The discovery of this mutual relationship between plants and PGPB has driven the development of new technologies aimed at using these microorganisms as biofertilizers (Richardson, 2001). Moreover, the isolation and characterization of new species of beneficial microorganisms, as well as the selection of isolates with desirable characteristics, are important steps in studies that aim to intensify agricultural production and promote the sustainability of these systems. In this sense, this study attempted to isolate and identify further bacteria with growth-promoting activities from sugarcane. The isolate Pantoea ananatis SCB4789F-1 was extracted from sugarcane leaves; its profile was then characterized in terms of phosphorus and zinc solubilization, indole-3-acetic acid (IAA) and siderophores production, and its ability to colonize Arabidopsis thaliana with effective promotion of plant growth.

\section{MATERIAL AND METHODS}

\section{Isolation and quantification of $P$. ananatis strain SCB4789F-1}

The bacterial strain SCB4789F-1 was isolated from sugarcane plants (cv. CB4789), multiplied from stalks, and grown for 3 months in a greenhouse located in Campos dos Goytacazes, Brazil $\left(21^{\circ} 36^{\prime} \mathrm{S} 41^{\circ} 35^{\prime} \mathrm{W}\right)$. 
Sugarcane root and leaf segments were used for bacterial isolation. These segments were washed first in running water to remove any remaining waste soil, and subsequently in sterile distilled water. Soon after, $1 \mathrm{~g}$ of the samples (root and leaf, respectively) was superficially fumigated with $70 \%$ ethanol for $2 \mathrm{~min}$, and washed twice in sterile distilled water for $3 \mathrm{~min}$. For disinfestation, roots were immersed in a $1 \%$ chloramine $\mathrm{T}$ solution for $10 \mathrm{~min}$, and leaves were again exposed to $70 \%$ ethanol for $3 \mathrm{~min}$. After surface disinfection, root and leaf samples were macerated in saline and subjected to serial dilutions. The samples were plated on LGI-P medium (Döbereiner et al., 1993) supplemented with $20 \mathrm{mg} / \mathrm{L}$ yeast extract and incubated at $30^{\circ} \mathrm{C}$ for 7 days. Subsequently, the obtained colonies were sub-cultured to obtain a pure culture of the isolate. The isolated strain was then stored in $50 \%$ glycerol at $-70^{\circ} \mathrm{C}$.

\section{S rDNA amplification and sequencing}

The genomic DNA of the isolate was extracted using a DNAzol Plant Extraction Kit (Invitrogen, Grand Island, NY, USA) according to the manufacturer instructions. The 16S rDNA sequence $(1.5 \mathrm{~kb})$ was amplified by polymerase chain reaction (PCR) with the following oligonucleotide primers for Eubacteria FD1 (5'-AGAGTTTGATCCTGGCTCAG-3') and RD1 domain (5'-AAGGAGGTGATCCAGCC-3') (Weisburg et al., 1991). Amplification of 16S rDNA was performed in a $20 \mu \mathrm{L}$ volume comprising: $10 \mathrm{mM}$ Tris- $\mathrm{HCl}, \mathrm{pH} 8.3 ; 50 \mathrm{mM} \mathrm{KCl} ; 1.5 \mathrm{mM} \mathrm{MgCl} ; 200$ $\mu \mathrm{M}$ of each deoxyribose nucleoside triphosphate (dNTP); 20 pmol oligonucleotide primers; 1 U Taq DNA polymerase; and $20 \mathrm{ng}$ DNA. The reaction was performed in a Mastercycler thermocycler (Gradient-Eppendorf, Applied Biosystems Inc., CA, USA) with an initial denaturation at $94^{\circ} \mathrm{C}$ for 3 min, followed by 30 cycles at $94^{\circ} \mathrm{C}$ for $60 \mathrm{~s}, 55^{\circ} \mathrm{C}$ for $30 \mathrm{~s}, 72^{\circ} \mathrm{C}$ for $30 \mathrm{~s}$, and a final extension at $72^{\circ} \mathrm{C}$ for $10 \mathrm{~min}$. The amplified products were purified using $70 \%$ ethanol and $100 \%$ isopropanol. The nucleotide sequence was determined by using an ABI PRISM 3130 Genetic Analyzer automatic sequencer (Applied Biosystems, CA, USA) and a BigDye Terminator kit according to the manufacturer instructions and using the set of oligonucleotides described in Table 1.

Table 1. Sequences of the primers used for amplification of the $16 \mathrm{~S}$ rDNA of the SCB4789F-1 strain isolated from sugarcane leaves.

\begin{tabular}{lcr}
\hline Sequence (5'-3') & Alignment position in the sequence of Escherichia coli & References \\
\hline CCT ACG GGA GGC AGC AG & $341-357 F$ & Lane, 1991 \\
CTG CTG CCT CCC GTA GG & $357-341 R$ & Lane, 1991 \\
GTA GSG GTG AAA TSC GTA GA & $685-704 \mathrm{~F}$ & Lane, 1991 \\
GTA GSG GTG AAA TSC GTA GA & $704-685 R$ & Lane, 1991 \\
GCA ACG AGC GCA ACC C & $1099-1114 \mathrm{~F}$ & Lane, 1991 \\
GGG TTG CGC TCG TTG C & $1114-1099 R$ & Lane, 1991 \\
\hline
\end{tabular}

\section{Phylogenetic analysis of the $16 \mathrm{~S}$ rDNA sequence}

The sequence of $16 \mathrm{~S}$ rDNA was compared using the GenBank database via the BLASTN algorithm (Altschul et al., 1997) to determine its similarity to other sequences. Sequences of $16 \mathrm{~S}$ rDNA ( 1500 bp) of different strains of $P$. ananatis and related genera were accessed through the GenBank database (http://www.ncbi.nlm.nih.gov/entrez) and aligned using the ClustalW 1.8 program (http://www.ebi.ac.uk/index.html). Subsequently, the adjustment of DNA sequence extremities was made with the aid of the BioEdit 5.0.6 program (Copyright ${ }^{\top} 1997-2013$, Carlsbad, $\mathrm{CA}$ ). To calculate the statistical significance of similarity between the sequences, a resampling for 
1000 replications was used (Swofford et al., 1996). The method of distance ("neighbor-joining") (Saitou and Nei, 1987) was used to construct the phylogenetic tree using the Geneious 4.8 program. The $16 \mathrm{~S}$ rDNA sequence of Escherichia coli was used as a phylogenetic tree outgroup.

\section{S rDNA sequence accession numbers}

The nucleotide sequence of the 16S rDNA of the bacterial strain SCB4789F-1, isolated in this study, was deposited at GenBank and assigned access number HM562980.

\section{Isolate biochemical profile}

The biochemical profile of the isolate was determined using the automatic identification system for members of the Enterobacteriaceae family, API-ID 32 GN Kit (bioMérieux SA, France). Isolate inoculation into this kit was performed according to manufacturer recommendations and, after 24-48 $\mathrm{h}$ incubation, strips were read and results were computed and analyzed by means of an ATB ${ }^{\circledR}$ instrument or a mini API. Oxidase and catalase tests were also performed to identify the isolate.

\section{Antibiotic resistance profile}

The resistance and/or susceptibility to antibiotics profile was determined by the diffusion method on Kirby-Bauer discs (NCCLS, 1983) in Mueller-Hinton culture medium. The resistance and/or susceptibility was tested for $20 \mu \mathrm{g} / \mathrm{mL}$ amoxicillin $+10 \mu \mathrm{g} / \mathrm{mL}$ clavulanic acid; $5 \mu \mathrm{g} / \mathrm{mL}$ ciprofloxacin; $10 \mu \mathrm{g} / \mathrm{mL}$ gentamicin; $300 \mu \mathrm{g} / \mathrm{mL}$ sulfazotrin; $30 \mu \mathrm{g} / \mathrm{mL}$ tetracycline; $30 \mu \mathrm{g} / \mathrm{mL}$ cephalothin; $30 \mu \mathrm{g} / \mathrm{mL}$ cefoxitin; $10 \mu \mathrm{g} / \mathrm{mL}$ ampicillin; $10 \mu \mathrm{g} / \mathrm{mL}$ tobramycin; and $30 \mu \mathrm{g} / \mathrm{mL}$ cephalexin. The plates were incubated at $30^{\circ} \mathrm{C}$ for $24 \mathrm{~h}$.

\section{Test of plant growth-promoting activities}

To evaluate the phosphorus and zinc solubilization potential of SCB4789F-1, the tests were carried out in LGI (Cavalcante and Döbereiner, 1988). Initially, the bacterial strain was grown in liquid medium DYGS for $18 \mathrm{~h}$ at $30^{\circ} \mathrm{C}$ and $140 \mathrm{rpm}$. After bacterial growth, $10 \mu \mathrm{L}$ aliquots of bacterial solutions $\left(10^{8}\right.$ cells $/ \mathrm{mL}$ ) were placed on petri dishes containing: LGI medium (constituents in g/L: 15 agar; 10 glucose; $0.2 \mathrm{~K}_{2} \mathrm{HPO}_{4} ; 0.6 \mathrm{KH}_{2} \mathrm{PO}_{4} ; 0.2 \mathrm{MgSO}_{4} \cdot 7 \mathrm{H}_{2} \mathrm{O} ; 0.02 \mathrm{CaCl}_{2} \cdot 2 \mathrm{H}_{2} \mathrm{O} ; 0.01$ $\left.\mathrm{FeCl}_{3} ; 0.002 \mathrm{Na}_{2} \mathrm{MoO}_{4} \cdot 2 \mathrm{H}_{2} \mathrm{O}, \mathrm{pH} 6\right)+0.54 \% \mathrm{Ca}_{5}\left(\mathrm{PO}_{4}\right)_{3} \mathrm{OH}$ or $0.12 \% \mathrm{ZnO}$; and LGI-P medium (constituents in $\mathrm{g} / \mathrm{L}$ : 15 agar; 100 crystal sugar; $0.2 \mathrm{~K}_{2} \mathrm{HPO}_{4} ; 0.6 \mathrm{KH}_{2} \mathrm{PO}_{4} ; 0.2 \mathrm{MgSO}_{4} \cdot 7 \mathrm{H}_{2} \mathrm{O} ; 0.02$ $\left.\mathrm{CaCl}_{2} \cdot 2 \mathrm{H}_{2} \mathrm{O} ; 0.01 \mathrm{FeCl}_{3} ; 0.002 \mathrm{Na}_{2} \mathrm{MoO}_{4} \cdot 2 \mathrm{H}_{2} \mathrm{O}, \mathrm{pH} 6\right)+0.54 \% \mathrm{Ca}_{5}\left(\mathrm{PO}_{4}\right)_{3} \mathrm{OH}$ or $0.12 \% \mathrm{ZnO}$. The petri dishes were incubated at $30^{\circ} \mathrm{C}$ for 7 days. Zinc and the phosphate solubilization was assessed by measuring the diameter of translucent halos formed around bacterial colonies. Production of indole compounds was tested using the Sarwar and Kremer (1995) method. Siderophore production was detected using the Schwyn and Neilands (1987) method with Chrome Azurol S dye. All experiments were performed in triplicate. Gluconacetobacter diazotrophicus PAL5 was used as a positive control.

\section{Inoculation and colonization tests}

The bacterial cultures were centrifuged at $12,000 \mathrm{~g}$ and, after discarding the supernatant, 
the cells were washed twice in sterile ultrapure water. The final optical density (0.01), measured using a spectrophotometer, was equivalent to $10^{6}$ cells $/ \mathrm{mL}$. Inoculum $(20 \mathrm{~mL}$ ) was added to the petri dishes containing 7-day-old $A$. thaliana seedlings; for the control material, an identical volume of sterile ultrapure water was added. After $3 \mathrm{~h}$, the seedlings were transferred into natural substrate West (West Garden, SP, Brazil) containing processed and enriched bark, expanded vermiculite and perlite, and expanded and processed peat. For 8 weeks, the plants were irrigated every 2 days with Hoagland nutrient solution (Hoagland and Arnon, 1950) containing $25 \%$ nutrients.

\section{Phenotypic analysis of plant growth promotion}

Plant shoots and roots were collected to determine the fresh matter weight. The wet weight was determined by weighing, using analytical scales, immediately after collection. For each treatment, 12 plants were evaluated.

\section{Statistical analysis}

The results were subjected to analysis of variance at $5 \%$ significance. Tukey's test was applied to identify whether the means differed significantly from each other $(P<0.05)$. Mean values and standard errors were calculated.

\section{RESULTS}

\section{Isolation and quantification of SCB4789F-1}

In this study, a bacterial strain called SCB4789F-1, which has potential for plant growth promotion, was isolated from sugarcane leaves. The strain SCB4789F-1 was isolated in LGI-P medium (Döbereiner et al. 1993) after 7 days of cultivation at $30^{\circ} \mathrm{C}$. The population of the isolate SCB4789F-1 in the sugarcane leaves was approximately $2 \times 10^{3}$ cells $/ g$ of plant tissue. The presence of the bacterium was not detected in the sugarcane root.

\section{Characteristics of plant growth promotion of SCB4789F-1}

The ability of the bacterium to solubilize nutrients, and produce indole compounds and siderophores was assessed. For reference, the data were compared with the endophytic bacterium G. diazotrophicus, which was also isolated from sugarcane and is a PGPB (Cavalcante and Döbereiner, 1988).

The ability to solubilize nutrients was assessed based on the presence or absence of a solubilization zone surrounding the colonies. According to Saravanan et al. (2007), the presence of this clear zone is related to the excretion of organic acids in the culture medium, which acidify the medium and contribute to the solubilization of the nutrients. The strain SCB4789F-1 was able to solubilize calcium phosphate $\left(\mathrm{Ca}_{5}\left(\mathrm{PO}_{4}\right)_{3} \mathrm{OH}\right)$ and zinc oxide $(\mathrm{ZnO})$ in the LGI medium (Table 2). In addition, SCB4789F-1 was able to produce indole compounds in both the absence and presence of tryptophan, although production was greater when the medium was supplemented with the amino acid (Table 2). The strain was also able to produce siderophores in the culture medium (Table 2). 
Table 2. Plant growth-promoting activities of SCB4789F-1. Gd (Gluconacetobacter diazotrophicus) PAL5 was used as a positive control.

\begin{tabular}{lcccc}
\hline Strain & $\begin{array}{c}\text { Diameter of halo of } \\
\text { P-solubilization }(\mathrm{cm})\end{array}$ & $\begin{array}{c}\text { Diameter of halo of } \\
\text { Zn-solubilization }(\mathrm{cm})\end{array}$ & $\begin{array}{c}\text { Indole production }(\mu \mathrm{mol} / \mathrm{L}) \\
\text { Siderophore } \\
\text { production }\end{array}$ \\
\hline SCB4789F-1 & $0.37 \pm 0.05^{\mathrm{b}}$ & $1.29 \pm 0.11^{\mathrm{b}}$ & $292 \pm 12^{\mathrm{b}}$ & $1.738 \pm 68^{\mathrm{a}}$ \\
Gd PAL5 & $1.04 \pm 0.1^{\mathrm{a}}$ & $1.93 \pm 0.12^{\mathrm{a}}$ & $434 \pm 65^{\mathrm{a}}$ & $665 \pm 12^{\mathrm{b}}$ \\
\hline
\end{tabular}

+ , positive Means followed by different letters differ statistically from each other at $5 \%$ significance. The values correspond to the means of three replicates.

\section{Biochemical characteristics of the isolate SCB4789F-1}

The isolate SCB4789F-1 was originally identified by means of biochemical tests, as suggested by Bergey's Manual of Systemic Bacteriology (Holt et al., 1994). The biochemical characterization tests revealed that the isolate was gram-negative, catalase-positive, and oxidase-negative. SCB4789F-1 gave positive results for all the other biochemical reactions tested except methyl red and propionic acid (Table 3). The isolate SCB4789F-1 grew well at $\mathrm{pH} 5.0-7.0$ and $30^{\circ} \mathrm{C}$. Based on the biochemical tests performed it was possible to identify the isolate as $P$. ananatis SCB4789F-1.

\section{Table 3. Biochemical characteristics of the strain SCB4789F-1.}

\begin{tabular}{|c|c|}
\hline Biochemical reactions & SCB4789F-1 \\
\hline Gram reaction & - \\
\hline Catalase & + \\
\hline Oxidase & - \\
\hline Sodium pyruvate & + \\
\hline Citrate & + \\
\hline Methyl red & - \\
\hline L-rhamnose & + \\
\hline D-sucrose & + \\
\hline D-ribose & + \\
\hline D-mannitol & + \\
\hline D-glucose & + \\
\hline D-melibiose & + \\
\hline D-sorbitol & + \\
\hline D-maltose & + \\
\hline Itaconic acid & + \\
\hline Suberic acid & + \\
\hline Propionic acid & - \\
\hline Capric acid & + \\
\hline Valeric acid & + \\
\hline Inositol & + \\
\hline L-arabinose & + \\
\hline $\mathrm{N}$-acetyl-glucosamine & + \\
\hline Sodium malonate & + \\
\hline Sodium acetate & + \\
\hline Lactic acid & + \\
\hline Potassium 5-ketogluconate & + \\
\hline L-serine & + \\
\hline L-alanine & + \\
\hline L-histidine & + \\
\hline L-proline & + \\
\hline
\end{tabular}

+ , tested positive/utilized as substrate; -, tested negative/not utilized as substrate. 


\section{$16 S$ rDNA sequencing for molecular identification}

Molecular identification of the isolate SCB4789F-1 was accomplished through the amplification and sequencing of $16 \mathrm{~S}$ rDNA $(\sim 1.5 \mathrm{~kb})$. The sequence obtained was $100 \%$ identical to sequences of $P$. ananatis available at GenBank. The phylogenetic tree (Figure 1) based on the 16S rDNA sequences of other members of the Enterobacteriaceae shows that the $P$. ananatis SCB4789F-1 isolate has a high level of sequence identity with other strains of $P$. ananatis and other species of the same genus. Henceforth, this isolate will be designated as $P$. ananatis SCB4789F-1.

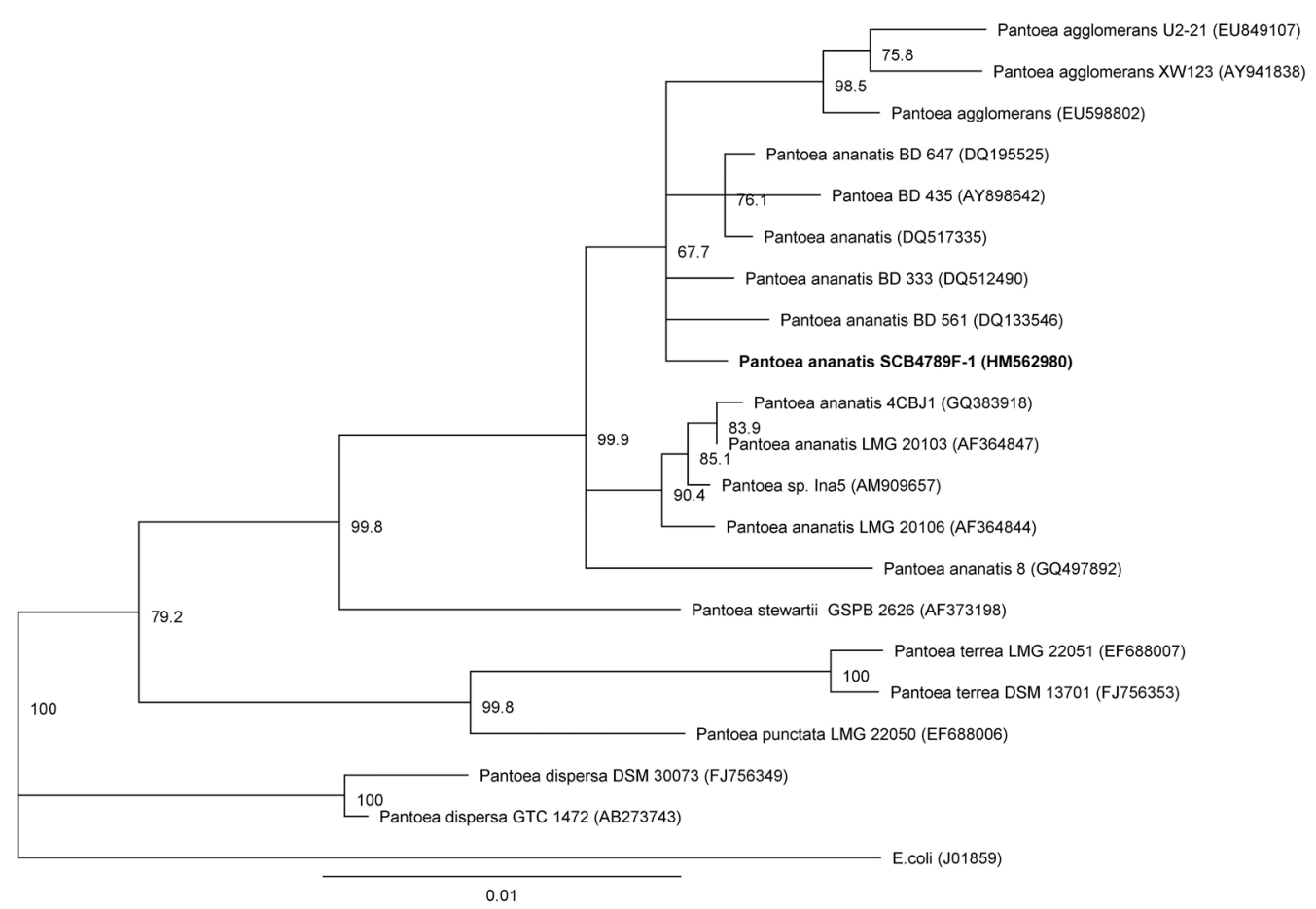

Figure 1. Phylogenetic tree showing the genetic relationship between Pantoea ananatis and other taxonomically similar strains and species of the same genus, based on $16 \mathrm{~S}$ rDNA. GenBank access numbers are in parentheses. We used the "neighbor-joining" method and the distances were calculated using the Jukes and Cantor method. The values on each branch represent percentages of 1000 bootstrap replicates. Escherichia coli was included as the outgroup. The scale is the similarity distance of the group in question. P. ananatis SCB4789F-1 is indicated in bold.

\section{Profile of antibiotic resistance in $P$. ananatis SCB4789F-1}

$P$. ananatis SCB4789F-1 proved to be moderately resistant to $10 \mu \mathrm{g} / \mathrm{mL}$ ampicillin and 30 $\mu \mathrm{g} / \mathrm{mL}$ cefoxitin, but was susceptible to the other tested antibiotics: $20 \mu \mathrm{g} / \mathrm{mL}$ amoxicillin $+10 \mu \mathrm{g} /$ $\mathrm{mL}$ clavulanic acid; $5 \mu \mathrm{g} / \mathrm{mL}$ ciprofloxacin; $10 \mu \mathrm{g} / \mathrm{mL}$ gentamicin; $300 \mu \mathrm{g} / \mathrm{mL}$ sulfazotrin; $30 \mu \mathrm{g} / \mathrm{mL}$ tetracycline; $30 \mu \mathrm{g} / \mathrm{mL}$ cephalothin; $10 \mu \mathrm{g} / \mathrm{mL}$ tobramycin; and $30 \mu \mathrm{g} / \mathrm{mL}$ cephalexin. 


\section{Effect of inoculation with $P$. ananatis SCB4789F-1 on the development of $A$. thaliana}

Seven-day-old $A$. thaliana seedlings were inoculated with $P$. ananatis SCB4789F-1 and after 60 days the ability of the bacterium to promote plant growth was evaluated. The inoculation with $P$. ananatis SCB4789F-1 resulted in a 37\% increase in fresh weight of the plant shoots compared with non-inoculated plants (control) (Figure 2A). However, there was no significant difference in the fresh root weight (Figure $2 \mathrm{~B}$ ). These data show that inoculation of $A$. thaliana seedlings with $P$. ananatis SCB4789F-1 efficiently promoted plant shoot growth (Figure 2A and 2C).
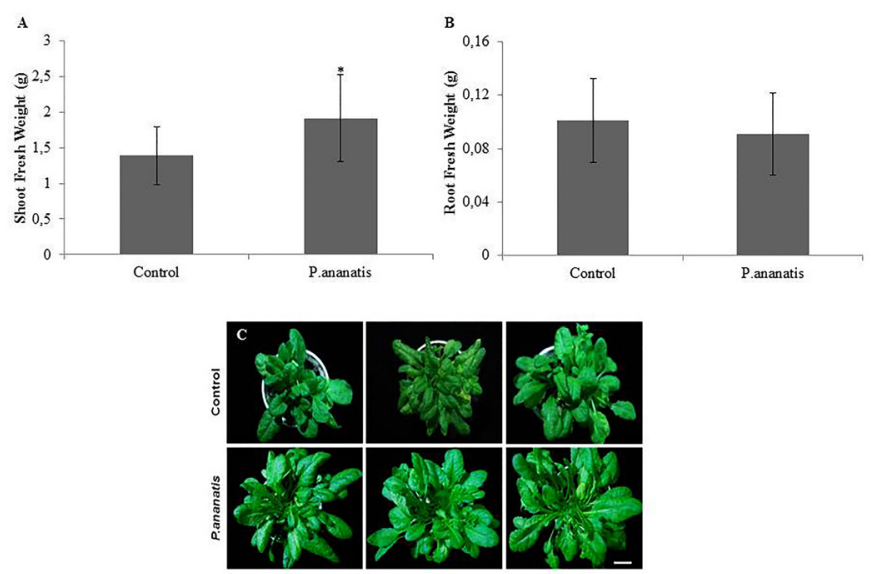

Figure 2. Plant growth promotion. Seedlings of Arabidopsis thaliana ecotype Col-0 were inoculated with Pantoea ananatis SCB4789F-1 after 7 days of germination. The control was not inoculated. After 60 days of inoculation, the shoot weight $(A)$ and the root weight $(B)$ were determined $(N=12)$. Representative photos of inoculated and control seedlings were taken $(C)$. The asterisk $\left({ }^{*}\right)$ indicates that the treatments differed statistically from each other at $5 \%$ significance according to the Student's t-test. The experiments were repeated three times and showed similar results. The white bar equals $1 \mathrm{~cm}$.

\section{DISCUSSION}

Isolation and selection of microorganisms with effective characteristics for plant growth are important steps in the development of new biofertilizers. In this study, we isolated $P$. ananatis SCB4789F-1 strain from sugarcane leaves and showed that it has multiple characteristics associated with plant growth promotion.

Although some studies have reported $P$. ananatis isolation from economically important crops, such as coffee (Nunes and de Melo, 2006), ginseng (Cho et al., 2007), papaya (Thomas et al., 2007), maize (Rijavec et al., 2007), and rice (Mano and Morisaki, 2008), they have failed to ascertain the essential growth parameters of this bacterium.

Here, the potential of $P$. ananatis SCB4789F-1 to promote plant growth has been demonstrated by its ability to solubilize phosphorus and zinc, produce siderophores, and synthesize IAA. In fact, only one other study on $P$. ananatis B1-9 strain isolated from the rhizosphere of onions showed potential for promoting plant growth in peppers, cucumbers, and melons (Kim et al., 2012).

The ability to solubilize phosphorus has been extensively reported for other species of the genus Pantoea (Ortega et al., 2008). However, no study has demonstrated the solubilization of zinc by $P$. ananatis or any other member of the genus. There are a few examples of bacteria 
associated with plants that are demonstrably able to solubilize zinc, such as Pseudomonas fluorescens, Pseudomonas aeruginosa, and G. diazotrophicus, (Di Simine et al., 1998; Fasim et al., 2002; Saravanan et al., 2007; Intorne et al., 2009). Microorganisms that solubilize phosphorus and zinc can mineralize and solubilize these nutrients from organic and inorganic mixtures of soil samples. The ability of $P$. ananatis SCB4789F-1 to solubilize phosphorus and zinc, and to enhance phytoremediation of soils contaminated with zinc, suggests the ecological advantage of making it available to plants.

The search for siderophore-producing microorganisms is of interest because they have a significant effect on plant nutrition when a plant suffers from iron deficiency. Moreover, siderophore production provides a competitive advantage for bacteria to colonize plant tissues and, especially, antagonize pathogenic microorganisms, which compete for the same ecological niche (Sharma and Johri, 2003). In this regard, studies carried out on rice showed that $P$. ananatis, which is able to secrete siderophores, has antagonistic activity against the pathogen Rhizoctonia solani (Yang et al., 2008). In cotton plants, the antagonistic effect of Pantoea spp against pathogenic fungi arising from siderophore secretion has also been demonstrated (Li et al., 2010).

Synthesis of IAA, which is an auxin, has been described for $P$. ananatis (Halda-Alija, 2003; Enya et al., 2007). Auxins are typically used in agriculture to stimulate plant growth through root development (Benjamins and Scheres, 2008). According to Kim et al. (2012), the production of IAA by $P$. ananatis B1-9 is the most important factor for growth and fruit production in pepper plants. Another study has shown that $P$. ananatis 125 NP12 isolated from tomato plants is capable of producing IAA. The authors suggested that IAA synthesis and an increased ability of the bacteria to colonize media showed a protective effect against gray mold disease on cut leaves (Enya et al., 2007).

Herein we report for the first time the successful inoculation of $A$. thaliana with $P$. ananatis SCB4789F-1. The ability to stimulate plant growth is considered to be a complex phenomenon. Therefore, current data on $A$. thaliana inoculation and its growth promotion should provide an important model system for studies on plant-bacteria interactions, with the availability of a wide range of plant mutants, knowledge of the genome, and ease of handling within a controlled environment. The demonstration that $P$. ananatis SCB4789F-1 promotes plant growth suggests future inoculation tests in other cultures of economic interest. Some studies have reported that $P$. ananatis inoculation in some crops such as pepper (Kang et al., 2007), papaya (Thomas et al., 2007), and maize (Rijavec et al., 2007) effectively improves plant yield. However, the mechanism behind the improvement has not yet been clarified. The efficient association of $P$. ananatis SCB4789F-1 with $A$. thaliana provides an important experimental tool for the elucidation of such mechanisms.

With increasing awareness of the harmful effects of agricultural practices based on chemical fertilizers, studies seeking to isolate and characterize microbial strains that can be used to promote growth in economically relevant crops have become important. In conclusion, this study reported that $P$. ananatis SCB4789F-1 has the essential characteristics for plant growth promotion, and its successful inoculation into $A$. thaliana stimulates shoot growth. Further studies evaluating the effect of this bacterium on promoting plant growth in economically relevant crops are warranted.

\section{Conflicts of interest}

The authors declare no conflict of interest.

\section{ACKNOWLEDGMENTS}

The authors thank CNPq, FAPERJ, and CAPES for financial support and fellowships. 


\section{REFERENCES}

Altschul SF, Madden TL, Schäffer AA, Zhang J, et al. (1997). Gapped BLAST and PSI-BLAST: a new generation of protein database search programs. Nucleic Acids Res. 25: 3389-3402.

Babar LK, Iftikhar T, Khan HN and Makhdum AH (2011). Agronomic trials on sugarcane crop under Faisalabad conditions, Pakistan. Pak. J. Bot. 43: 929-935.

Benjamins R and Scheres B (2008). Auxin: the looping star in plant development. Annu. Rev. Plant Biol. 59: 443-465.

Berg G (2009). Plant-microbe interactions promoting plant growth and health: perspectives for controlled use of microorganisms in agriculture. Appl. Microbiol. Biotechnol. 84: 11-18.

Cavalcante VA and Döbereiner J (1998). A new acid-tolerant nitrogen-fixing bacterium associated with sugarcane. Plant Soil 108: 23-31.

Cho KM, Hong SY, Lee SM, Kim YH, et al. (2007). Endophytic bacterial communities in ginseng and their antifungal activity against pathogens. Microb. Ecol. 54: 341-351.

Compant S, Duffy B, Nowak J, Clément C, et al. (2005). Use of plant growth-promoting bacteria for biocontrol of plant diseases: principles, mechanisms of action, and future prospects. Appl. Environ. Microbiol. 71: 4951-4959.

Dion P, Uribe D, Sanchez-Nieves J and J Vanegas (2010). Role of microbial biofertilizers in the development of a sustainable agriculture in the tropics. In: Soil biology and agriculture in the tropics. Springer, Berlin Heidelberg, 235-250.

Di Simine CD, Sayer JA and Gadd GM (1998). Solubilization of zinc phosphate by a strain of Pseudomonas fluorescens isolated from a forest soil. Biol. Fertil. Soils 28: 87-94.

Döbereiner J (1993). Recent changes in concepts of plant bacteria interactions: endophytic $\mathrm{N}_{2}$ fixing bacteria. Cienc. Cult. 44 : 310-313.

Enya J, Shinohara H, Yoshida S, Tsukiboshi T, et al. (2007). Culturable leaf-associated bacteria on tomato plants and their potential as biological control agents. Microb. Ecol. 53: 524-536.

Fasim F, Ahmed N, Parsons R and Gadd GM (2002). Solubilization of zinc salts by a bacterium isolated from the air environment of a tannery. FEMS Microbiol. Lett. 213: 1-6.

Halda-Alija L (2003). Identification of indole-3-acetic acid producing freshwater wetland rhizosphere bacteria associated with Juncus effusus L. Can. J. Microbiol. 49: 781-787.

Hoagland DR and Arnon DI (1950). The water-culture method for growing plants without soil. College of Agriculture, University of California in Berkeley.

Holt JG, Krieg NR, Sneath PHA, Staley JT, et al. (1994). Bergey's Manual of Determinative Bacteriology, 9th edn. Williams and Wilkins, Baltimore.

IFA (International Fertilizer Industry Association) (2014). Book International Fertilizer Industry Association, Available at [http:// www.fertilizer.org/].

Intorne AC, de Oliveira MV, Lima ML, da Silva JF, et al. (2009). Identification and characterization of Gluconacetobacter diazotrophicus mutants defective in the solubilization of phosphorus and zinc. Arch. Microbiol. 191: 477-483.

Jukes TH and Cantor CR. (1969). Evolution of protein molecules. Mammalian protein metabolism. H. N. Munro. New York, Academic Press: 2-4.

Kang SH1, Cho HS, Cheong H, Ryu CM, et al. (2007). Two bacterial entophytes eliciting both plant growth promotion and plant defense on pepper (Capsicum annuum L.). J. Microbiol. Biotechn. 17: 96-103.

Kim SN, Cho WK, Kim WI, Jee HJ, et al. (2012). Growth Promotion of Pepper Plants by Pantoea ananatis B1-9 and its Efficient Endophytic Colonization Capacity in Plant Tissues. Plant Pathol. J. 28: 270-281.

Lane DJ (1991). 16S/23S rRNA sequencing. In: Nucleic acid techniques in bacterial systematics (Stackebrandt E and Goodfellow M, eds.). John Wiley and Sons, Chichester.

Lee S, Flores-Encarnación M, Contreras-Zentella M, Garcia-Flores L, et al. (2004). Indole-3-acetic acid biosynthesis is deficient in Gluconacetobacter diazotrophicus strains with mutations in cytochrome c biogenesis genes. J. Bacteriol. 186: 5384-5391.

$\mathrm{Li} \mathrm{CH}$, Zhao MW, Tang CM and Li SP (2010). Population dynamics and identification of endophytic bacteria antagonistic toward plant-pathogenic fungi in cotton root. Microb. Ecol. 59: 344-356.

Lodewyckx C, Mergeay M, Vangronsveld J, Clijsters H, et al. (2002). Isolation, characterization, and identification of bacteria associated with the zinc hyperaccumulator Thlaspi caerulescens subsp. calaminaria. Int. J. Phytoremediation 4: 101-115.

Mano $\mathrm{H}$ and Morisaki H (2008). Endophytic bacteria in the rice plant. Microbes Environ. 23: 109-117.

National Committee for Clinical Laboratory Standards (NCCLS) (1983). Performance standards for antimicrobial disc susceptibility tests. Approved standard M2-A2. National Committee for Clinical Laboratory Standards, Villanova.

Nunes FV and de Melo IS (2006). Isolation and characterization of endophytic bacteria of coffee plants and their potential in caffeine degradation. In: Environmental Toxicology (Kungolos AG, Brebbia CA, Samaras CP and Popov V, eds.). WIT Press, Southampton. 
Ortega E, Cordero Elvia J and Ortega-Rodés P (2008). Plant inoculation with Pantoea sp., phosphate solubilising-bacteria increases $\mathrm{P}$ concentration in leaf tissues. Rev. Colomb. Biotecnol. 10: 111-121.

Richardson AE (2001). Prospects for using soil microorganisms to improve the acquisition of phosphorus by plants. Aust. J. Plant Physiol. 28: 897-906.

Rijavec T, Lapanje A, Dermastia M and Rupnik M (2007). Isolation of bacterial endophytes from germinated maize kernels. Can. J. Microbiol. 53: 802-808.

Ryan RP, Germaine K, Franks A, Ryan DJ, et al. (2008). Bacterial endophytes: recent developments and applications. FEMS Microbiol. Lett. 278: 1-9.

Saitou N and Nei M (1987). The neighbor-joining method: a new method for reconstructing phylogenetic trees. Mol. Biol. Evol. 4: 406-425.

Saravanan VS, Madhaiyan M and Thangaraju M (2007). Solubilization of zinc compounds by the diazotrophic, plant growth promoting bacterium Gluconacetobacter diazotrophicus. Chemosphere. 66: 1794-1798.

Sarwar M and Kremer RJ (1995). Determination of bacterially derived auxins using a microplate method. Letters in Applied Microbiology 20: 282-285.

Schwyn B and Neilands JB (1987). Universal chemical assay for the detection and determination of siderophores. Anal. Biochem. 160: 47-56.

Sharma A and Johri BN (2003). Growth promoting influence of siderophore-producing Pseudomonas strains GRP3A and PRS9 in maize (Zea mays L.) under iron limiting conditions. Microbiol. Res. 158: 243-248.

Swofford DL, Olsen GJ, Waddell PJ and Hillis DM (1996). Phylogenetic inference. In: Molecular systematics (Hillis DM, Moritz $\mathrm{C}$ and Mable BK, eds.). Sinauer Associates, Sunderland.

Thomas P, Kumari S, Swarna GK and Gowda TK (2007). Papaya shoot tip associated endophytic bacteria isolated from in vitro cultures and host-endophyte interaction in vitro and in vivo. Can. J. Microbiol. 53: 380-390.

Verma SC, Ladha JK and Tripathi AK (2001). Evaluation of plant growth promoting and colonization ability of endophytic diazotrophs from deep water rice. J. Biotechnol. 91: 127-141.

Weisburg WG, Barns SM, Pelletier DA and Lane DJ (1991). 16S ribosomal DNA amplification for phylogenetic study. J. Bacteriol. 173: 697-703.

Yang JH, Liu HX, Zhu GM and Pan YL (2008). Diversity analysis of antagonists from rice-associated bacteria and their application in biocontrol of rice diseases. J. Appl. Microbiol. 104: 91-104. 